\title{
Lactobacillus ghanensis sp. nov., a motile lactic acid bacterium isolated from Ghanaian cocoa fermentations
}

Correspondence

Dennis S. Nielsen

dn@life.ku.dk

\author{
Dennis S. Nielsen, ${ }^{1}$ Ulrich Schillinger, ${ }^{2}$ Charles M. A. P. Franz, ${ }^{2}$ \\ José Bresciani, ${ }^{3}$ Wisdom Amoa-Awua, ${ }^{4}$ Wilhelm H. Holzapfel ${ }^{2}$ \\ and Mogens Jakobsen ${ }^{1}$
}

\author{
${ }^{1}$ Department of Food Science, Food Microbiology, Centre for Advanced Food Studies (LMC), \\ Faculty of Life Sciences, Copenhagen University, Rolighedsvej 30, 1958 Frederiksberg C, \\ Denmark \\ ${ }^{2}$ Institute for Hygiene and Toxicology, Federal Research Centre for Nutrition and Food, \\ Karlsruhe, Germany \\ ${ }^{3}$ Department of Ecology, Faculty of Life Sciences, Copenhagen University, Copenhagen, \\ Denmark \\ ${ }^{4}$ CSIR - Food Research Institute, Accra, Ghana
}

Cocoa beans, the principal raw material of chocolate, have to be fermented, dried and roasted to produce the characteristic cocoa flavour and taste. The fermentation of cocoa is a microbiologically complex process involving the activities of yeasts, lactic acid bacteria and acetic acid bacteria (Schwan \& Wheals, 2004). During an investigation of the micro-organisms involved in the fermentation of cocoa beans, a number of isolates with unusual properties were isolated from MRS agar and tentatively identified as Lactobacillus species (Nielsen et al., 2007). This study presents the morphological, biochemical and molecular characterization of three of these isolates, designated L486, $\mathrm{L} 489^{\mathrm{T}}$ and $\mathrm{L} 499$.

The GenBank/EMBL/DDBJ accession numbers for the 16S rRNA gene sequences of strains L486, L489 ${ }^{\top}$ and L499 are D0867003, D0523489 and D0867004, respectively.

Maximum-likelihood and maximum-parsimony phylogenetic trees based on $16 \mathrm{~S}$ rRNA gene sequences showing the phylogenetic position of strains $L 486, L 489^{\top}$ and $L 499$ within the $L$. casei cluster are available as supplementary figures with the online version of this article.
Strains L486, L489 ${ }^{\mathrm{T}}, \mathrm{L} 499$ and the reference strains Lactobacillus nagelii DSM $13675^{\mathrm{T}}$, Lactobacillus satsumensis DSM $16230^{\mathrm{T}}$ and Lactobacillus vini DSM $20605^{\mathrm{T}}$ were grown in MRS broth (Merck) at $30^{\circ} \mathrm{C}$ for 2-3 days; for long-term storage, $20 \%$ glycerol was added and the cultures were stored at $-80^{\circ} \mathrm{C}$.

The cell morphologies of cultures grown overnight in MRS broth $\left(30^{\circ} \mathrm{C}\right)$ were determined using phase-contrast microscopy and scanning electron microscopy. For the latter, $30 \mu \mathrm{l}$ culture diluted 10 -fold with sterile MilliQ water was filtered through a polycarbonate filter (pore size, $0.2 \mu \mathrm{m}$ ), exposed to osmium vapour for $1 \mathrm{~h}$ and coated with goldpalladium. Cells were observed in a FEI Quanta 200 scanning electron microscope at $15 \mathrm{kV}$. The cells were rodshaped $(0.7-0.8 \times 1.4-2.5 \mu \mathrm{m})$, occurring either singly, in pairs or in short chains of three to four cells (Fig. 1). The cells were observed to be highly motile under the phasecontrast microscope. Scanning electron microscopy showed the presence of peritrichous flagella (Fig. 1). 


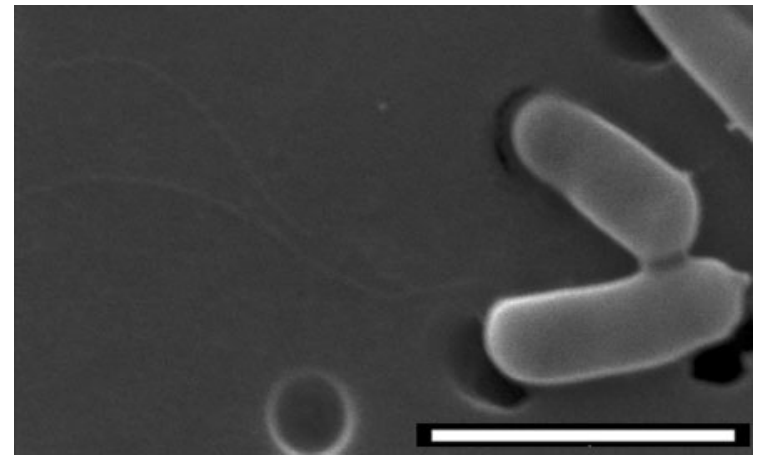

Fig. 1. Scanning electron micrograph of cells of strain $L 489^{\top}$ grown overnight in MRS broth at $30^{\circ} \mathrm{C}$, showing the presence of flagella. Bar, $2 \mu \mathrm{m}$.

Colonies grown on MRS agar (Merck) incubated anaerobically for 4 days at $30^{\circ} \mathrm{C}$ were $2-3 \mathrm{~mm}$ in diameter, white to creamy white, smooth, circular, convex and with entire or slightly uneven margins. If cultures were incubated aerobically ( 4 days, $30^{\circ} \mathrm{C}$ ), the colonies were pinpoint-sized.

The Gram reaction and catalase activity were tested using standard methods. Growth at 15 and $45^{\circ} \mathrm{C}$ (in MRS broth), in the presence of $6.5 \% \mathrm{NaCl}$ and at $\mathrm{pH} 3.9$ and 8.0, gas production from glucose (in MRS broth, with inverted Durham tubes, and determined at $30^{\circ} \mathrm{C}$ ), the production of ammonia from arginine and the presence of D-mesodiaminopimelic acid in the cell wall were tested by following the protocol of Schillinger \& Lücke (1987). The configuration of the lactic acid enantiomer produced was determined enzymically (Boehringer Mannheim) (Schillinger \& Lücke, 1987).

The carbohydrate-fermentation patterns of strains L486, $\mathrm{L} 489^{\mathrm{T}}$ and L499 were determined in microtitre plates by following the protocol of Jayne-Williams (1976) and, in addition, using the API $50 \mathrm{CHL}$ identification system (bioMérieux).
For 16S rRNA gene sequencing, DNA was extracted using the method of Björkroth \& Korkeala (1996) and the almostcomplete 16S rRNA gene was amplified using primers $7 \mathrm{f}$ and 1510r (Lane, 1991; Björkroth \& Korkeala, 1996). All reactions were carried out in a $50 \mu \mathrm{l}$ volume containing 1.25 U Taq DNA polymerase (Amersham Biosciences), $5 \mu \mathrm{l}$ $10 \times$ PCR buffer (Amersham Biosciences), $200 \mu \mathrm{M}$ each dNTP (Amersham Biosciences), $3.0 \mathrm{mM} \mathrm{MgCl}_{2}$ (Amersham Biosciences), $0.1 \mu \mathrm{M}$ each primer (DNA Technologies), $1 \%$ $(\mathrm{v} / \mathrm{v})$ formamide (Merck), $0.1 \%(\mathrm{w} / \mathrm{v})$ BSA (New England Biolabs), 20 ng DNA template and sufficient sterile MilliQ water to adjust the volume to $50 \mu$ l. The PCR was performed using the following thermocycling program: 5 min initial denaturation at $94^{\circ} \mathrm{C}, 30$ cycles of $94^{\circ} \mathrm{C}$ for $90 \mathrm{~s}, 52^{\circ} \mathrm{C}$ for $30 \mathrm{~s}$ and $72^{\circ} \mathrm{C}$ for $90 \mathrm{~s}$ and then a final elongation step at $72{ }^{\circ} \mathrm{C}$ for $7 \mathrm{~min}$. Following purification (using the Qiagen PCR purification kit), the PCR products were sequenced in both directions using a CEQ 2000 automated sequencer (Beckman Coulter) and a CEQ 2000 Dye Terminator Cycle Sequencing Quick Start kit (Beckman Coulter) or sent to a commercial sequencing facility (DNA Technology A/S, Aarhus, Denmark). Sequences were corrected manually and aligned using Vector NTI Suite 7 (Informax). The closest phylogenetic relatives were determined by aligning the corrected sequences with $16 \mathrm{~S}$ rRNA gene sequences in the GenBank database by using the BLAST algorithm (Altschul et al., 1997). Strains L486 and $\mathrm{L} 489^{\mathrm{T}}$ had $100 \%$ identical $16 \mathrm{~S}$ rRNA gene sequences, whereas L499 differed by one nucleotide from the former two. The $16 \mathrm{~S}$ rRNA gene sequences of strains L486, L489 ${ }^{\mathrm{T}}$, L499 and the sequences of the closest phylogenetic relatives retrieved from the GenBank database were aligned and phylogenetic trees constructed with the neighbour-joining, maximum-likelihood and maximumparsimony methods using BIONUMERICS, version 3.5 (Applied Maths). Unknown bases were disregarded for the analysis; $1450 \mathrm{nt}$ were included. The statistical reliability of the topology of the phylogenetic trees was evaluated using bootstrap resampling of the data (1000 resamplings) (Fig. 2; also see Supplementary Figs S1 and S2 available in IJSEM Online). In comparisons between the $16 \mathrm{~S}$ rRNA gene sequence of $\mathrm{L} 489^{\mathrm{T}}$ and those of type strains in the GenBank

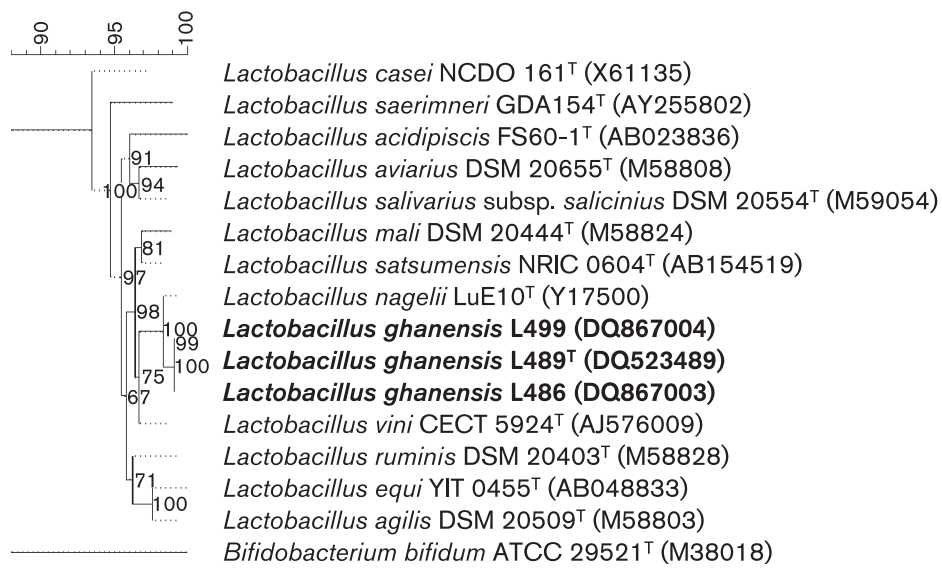

Fig. 2. Neighbour-joining phylogenetic tree, based on almost-complete 16S rRNA gene sequences, showing the phylogenetic position of strains $\mathrm{L}^{486}$, L489 ${ }^{\mathrm{T}}$ and $\mathrm{L} 499$ within the Lactobacillus casei cluster of microorganisms (accession numbers are shown in parentheses). Bootstrap percentages (based on 1000 replications) are shown at nodes. 
database, the highest levels of similarity were with $L$. nagelii DSM $13675^{\mathrm{T}}$ (98.0\%), L. satsumensis DSM $16230^{\mathrm{T}}(95.5 \%)$ and L. vini DSM $20605^{\mathrm{T}}(93.7 \%)$ (Table 1$)$.

For determinations of the $\mathrm{G}+\mathrm{C}$ content and DNA-DNA hybridization levels, DNA was extracted from L489 ${ }^{\mathrm{T}}$, L499, L. nagelii DSM $13675^{\mathrm{T}}$ and L. satsumensis DSM $16230^{\mathrm{T}}$ and purified according to the protocol of Marmur (1961), as modified by Stackebrandt \& Kandler (1978). Strain L486 was not included in the DNA-DNA hybridization studies, as the $16 \mathrm{~S}$ rRNA gene sequence is $100 \%$ identical to that of strain $\mathrm{L} 489^{\mathrm{T}}$. The DNA G $+\mathrm{C}$ content was determined from the thermal melting temperature $\left(T_{\mathrm{m}}\right)$ of the DNA by using a Cary 100 Bio UV-visible spectrophotometer (Varian). DNA-DNA relatedness was determined spectrophotometrically from renaturation rates (De Ley et al., 1970). DNAs from strains $\mathrm{L} 489^{\mathrm{T}}$ and L499 were hybridized with each other and with DNA from L. nagelii DSM $13675^{\mathrm{T}}$ and with DNA from L. satsumensis DSM $16230^{\mathrm{T}}$. The reassociation value between $\mathrm{L} 489^{\mathrm{T}}$ and $\mathrm{L} 499$ was $92.5 \%$, indicating that the strains are conspecific. Reassociation values of $18-44 \%$ were obtained with respect to L. nagelii DSM $13675^{\mathrm{T}}$ and values of $0-12 \%$ were obtained with respect to L. satsumensis DSM $16230^{\mathrm{T}}$. All of the DNA-DNA hybridization values obtained for the closest relatives, namely $L$. nagelii DSM $13675^{\mathrm{T}}$ and L. satsumensis DSM $16230^{\mathrm{T}}$, were therefore well below the $70 \%$ cut-off value that indicates separate species (Wayne et al., 1987). DNA reassociation values were not determined for $\mathrm{L} 489^{\mathrm{T}}$ and $\mathrm{L} 499$ with respect to the phylogenetically closely related species $L$. vini, as $L$. vini does not contain D-meso-diaminopimelic acid in the cell wall (Table 1). The DNA G $+\mathrm{C}$ content for strain $\mathrm{L} 489^{\mathrm{T}}$ and for strain L499 was $37.8 \mathrm{~mol} \%$, while those for L. nagelii DSM $13675^{\mathrm{T}}$ and L. satsumensis DSM $16230^{\mathrm{T}}$ were 37.7 and $40.2 \mathrm{~mol} \%$, respectively (Table 1 ).

The three strains were also investigated genotypically by using repetitive element palindromic-PCR with the primer $\mathrm{GTG}_{5}$ according to the method of Gevers et al. (2001) for lactic acid bacteria, as described previously (Franz et al., 2006). Strains L486, L489 ${ }^{\mathrm{T}}$ and L499 clustered closely $(r=85 \%)$ and were only distantly related to the type strains of L. nagelii, L. satsumensis and L. vini (Fig. 3).

On the basis of the above-mentioned data, it can be concluded that strains L486, L489 ${ }^{\mathrm{T}}$ and $\mathrm{L} 499$ form a homogeneous, distinct genetic group and are most closely related to L. nagelii and L. satsumensis. Phenotypically, strains L486,

Table 1. Differential phenotypic features of strains $L 486, L 489^{\top}$ and $L 499$ and motile Lactobacillus species and L. mali

Taxa: 1, strains L486, L489 ${ }^{\mathrm{T}}$ and L499; 2, L. nagelii; 3, L. satsumensis; 4, L. vini; 5, L. agilis; 6, L. ruminis; 7, L. curvatus subsp. curvatus; 8, L. mali. L. mali is non-motile but is phylogenetically closely related to strains L486, L489 ${ }^{\mathrm{T}}$ and L499 and is thus included for comparison. Data are taken in part from Edwards et al. (2000), Endo \& Okada (2005), Hammes \& Hertel (2006), Kato et al. (2000), Rodas et al. (2006) and Torriani et al. (1996). +, Positive; -, negative; W, weak; d, strain-dependent; ND, no data.

\begin{tabular}{|c|c|c|c|c|c|c|c|c|}
\hline Characteristic & 1 & 2 & 3 & 4 & 5 & 6 & $7^{\star}$ & $8 \dagger$ \\
\hline \multicolumn{9}{|l|}{ Growth in MRS broth in/at: } \\
\hline $15^{\circ} \mathrm{C}$ & $\mathrm{w}$ & + & + & - & - & - & + & + \\
\hline $45^{\circ} \mathrm{C}$ & + & + & + & + & + & $\mathrm{d}$ & - & - \\
\hline $6.5 \% \mathrm{NaCl}$ & - & + & + & + & ND & ND & ND & - \\
\hline pH 3.9 & $\mathrm{w}$ & + & + & + & ND & ND & ND & ND \\
\hline pH 8.0 & - & + & ND & + & ND & ND & ND & - \\
\hline Lactate isomer(s) & $\mathrm{DL}$ & DL & $\mathrm{L}$ & DL & $\mathrm{L}$ & $\mathrm{L}$ & DL & $\mathrm{L}$ \\
\hline \multicolumn{9}{|l|}{ Acid from: } \\
\hline L-Arabinose & - & - & - & + & - & - & - & + \\
\hline D-Cellobiose & + & + & - & + & + & + & d & + \\
\hline Mannitol & + & + & + & - & + & - & - & - \\
\hline Raffinose & - & - & - & - & + & + & - & - \\
\hline L-Rhamnose & + & + & + & - & - & - & - & $\mathrm{d}$ \\
\hline Sorbitol & $\mathrm{d}$ & + & - & - & $\mathrm{d}$ & - & - & - \\
\hline Dextran from sucrose & - & + & + & - & ND & ND & ND & + \\
\hline D-meso-Diaminopimelic acid in cell wall & + & + & + & - & + & + & - & + \\
\hline DNA G $+C$ content $(\mathrm{mol} \%)$ & 37.8 & 37.7 & 40.2 & 39.4 & $43-44$ & $44-47$ & $42-44$ & $32-34$ \\
\hline $\begin{array}{l}\text { 16S rRNA gene sequence similarity }(\%) \\
\text { with respect to strain } \mathrm{L} 489^{\mathrm{T}}\end{array}$ & $99.9-100$ & 98.0 & 95.5 & 93.7 & 90.3 & 92.3 & 89.9 & 91.9 \\
\hline
\end{tabular}

${ }^{*}$ Some strains are motile but lose their motility when subcultured (Torriani et al., 1996).

†Some strains have been reported to be motile (Kaneuchi et al., 1998). 
$r \times 100$

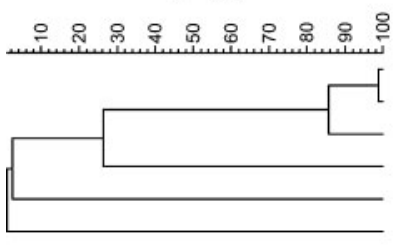

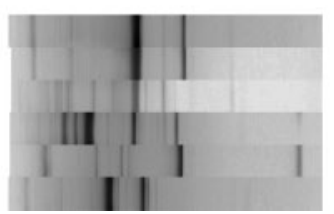

Fig. 3. (GTG) $)_{5}-P C R$ fingerprints and corresponding dendrogram, derived from UPGMA linkage of correlation coefficients ( $r$, expressed as a percentage for convenience), for strains $\mathrm{L} 486, \mathrm{~L} 489^{\mathrm{T}}$ and $\mathrm{L} 499$ and related lactobacilli.
L489 ${ }^{\mathrm{T}}$ and L499 are closely related to L. nagelii, but the absence of growth at $\mathrm{pH} 8.0$ and with $6.5 \% \mathrm{NaCl}$, absent or weak growth at $\mathrm{pH} 3.9$, the inability to produce acid from sorbitol and tagatose (although delayed positive reactions were observed in strain L499) and the absence of dextran production from glucose are features that serve to differentiate strains $\mathrm{L} 486, \mathrm{~L} 489^{\mathrm{T}}$ and $\mathrm{L} 499$ from $L$. nagelii (Table 1).

The results obtained in the present study clearly indicate that the strains studied represent a novel species within the genus Lactobacillus, for which the name Lactobacillus ghanensis sp. nov. is proposed. The type strain is $\mathrm{L} 489^{\mathrm{T}}(=\mathrm{DSM}$ $18630^{\mathrm{T}}=$ CCUG $53453^{\mathrm{T}}$ ).

\section{Description of Lactobacillus ghanensis sp. nov.}

Lactobacillus ghanensis (ghan.en'sis. N.L. masc. adj. ghanensis pertaining to Ghana, where the micro-organism was first isolated).

Cells are rod-shaped, $0.7-0.8 \times 1.4-2.5 \mu \mathrm{m}$ in size and occur singly, in pairs or in short chains comprising three to four cells. Gram-positive, catalase-negative, motile with peritrichous flagella and non-spore-forming. Colonies are 2$3 \mathrm{~mm}$ in diameter, white to creamy white, smooth, circular, convex and with entire or slightly uneven edges after 3-4 days of anaerobic growth. Weak growth at $15^{\circ} \mathrm{C}$; good growth at $45{ }^{\circ} \mathrm{C}$. No growth occurs at $6.5 \% \mathrm{NaCl}$. Weak growth at $\mathrm{pH} 3.9$; no growth at $\mathrm{pH}$ 8.0. Ammonia is not produced from arginine. No gas is produced from glucose. $\mathrm{D}(-)$ - and $\mathrm{L}(+)$-lactic acid are produced as the end products from glucose metabolism. Acid is produced from amygdalin, D-cellobiose, aesculin, D-fructose, D-glucose, D-galactose, D-mannitol, D-mannose, $\mathrm{N}$-acetylglucosamine, L-rhamnose, sucrose, salicin and D-trehalose. Acid is not produced from D-adonitol, starch, D-arabinose, L-arabinose, arbutin, dulcitol, erythritol, D-fucose, L-fucose, gentiobiose, gluconate, glycogen, inositol, inulin, D-lyxose, D-melezitose, D-melibiose, methyl $\beta$-xyloside, D-raffinose, D-ribose, D-sorbitol, D-turanose, xylitol, D-xylose, L-xylose, 2-ketogluconate or 5-ketogluconate. Acid production from glycerol, D-lactose, D-maltose, methyl $\alpha$-D-glucoside (delayed reaction), D-sorbitol (delayed reaction), L-sorbose and D-tagatose (delayed reaction) is strain-dependent. Does not produce dextran from sucrose. The cell wall contains peptidoglycan of the D-meso-diaminopimelic acid type. The DNA G + C content is $37.8 \mathrm{~mol} \%$.
The type strain, $\mathrm{L} 489^{\mathrm{T}}\left(=\mathrm{DSM} 18630^{\mathrm{T}}=\right.$ CCUG $\left.53453^{\mathrm{T}}\right)$, and all other known strains of the species were isolated from cocoa fermentations in Tafo, Ghana. The description of the type strain corresponds to the description of the species except that no acid is produced from glycerol, maltose, methyl $\alpha$-D-glucoside, D-lactose, sorbitol or tagatose. Strain L499 ( = DSM $18631=$ CCUG 53454) is a reference strain.

\section{Acknowledgements}

The work described here was partly financed through the EU INCO project 'Developing biochemical and molecular markers for determining quality assurance in the primary processing of cocoa in West Africa - COCOQual' (ICA4-CT-2002-10040). The cooperation, and invaluable technical assistance, of the Cocoa Research Institute of Ghana (and of Dr J. S. Takrama in particular) is greatly appreciated.

\section{References}

Altschul, S. F., Madden, T. L., Schäffer, A. A., Zhang, J., Zhang, Z., Miller, W. \& Lipman, D. J. (1997). Gapped BLAST and PSI-BLAST: a new generation of protein database search programs. Nucleic Acids Res 25, 3389-3402.

Björkroth, J. \& Korkeala, H. (1996). Evaluation of Lactobacillus sake contamination in vacuum-packaged sliced cooked meat products by ribotyping. J Food Prot 59, 2854-2858.

De Ley, J., Cattoir, H. \& Reynaerts, A. (1970). The quantitative measurement of DNA hybridisation from renaturation rates. Eur J Biochem 12, 133-142.

Edwards, C. G., Collins, M. D., Lawson, P. A. \& Rodriguez, A. V. (2000). Lactobacillus nagelii sp. nov., an organism isolated from a partially fermented wine. Int J Syst Evol Microbiol 50, 699-702.

Endo, A. \& Okada, S. (2005). Lactobacillus satsumensis sp. nov., isolated from mashes of shochu, a traditional Japanese distilled spirit made from fermented rice and other starchy materials. Int J Syst Evol Microbiol 55, 83-85.

Franz, C. M. A. P., Vancanneyt, M., Vandemeulebroecke, K., De Wachter, M., Cleenwerck, I., Hoste, B., Schillinger, U., Holzapfel, W. H. \& Swings, J. (2006). Pediococcus stilesii sp. nov., isolated from maize grains. Int J Syst Evol Microbiol 56, 329-333.

Gevers, D., Huys, G. \& Swings, J. (2001). Applicability of rep-PCR fingerprinting for identification of Lactobacillus species. FEMS Microbiol Lett 205, 31-36.

Hammes, W. P. \& Hertel, C. (2006). The genera Lactobacillus and Carnobacterium. In The Prokaryotes. A Handbook on the Biology of Bacteria, 3rd edn, vol. 4, pp. 320-403. Edited by M. Dworkin, S. Falkow, E. Rosenberg, K. H. Schleifer \& E. Stackebrandt. New York: Springer. 
Jayne-Williams, D. J. (1976). The application of miniaturized methods for the characterization of various organisms isolated from the animal gut. J Appl Bacteriol 40, 189-200.

Kaneuchi, C., Seki, M. \& Komagata, K. (1998). Taxonomic study of Lactobacillus mali Carr and Davis 1970 and related strains: validation of Lactobacillus mali Carr and Davis 1970 over Lactobacillus yamanashiensis Nonomura 1983. Int J Syst Bacteriol 38, 269-272.

Kato, Y., Sakala, R. M., Hayashidani, H., Kiuchi, A., Kaneuchi, C. \& Ogawa, M. (2000). Lactobacillus algidus sp. nov., a psychrophilic lactic acid bacterium isolated from vacuum-packaged refrigerated beef. Int J Syst Evol Microbiol 50, 1143-1149.

Lane, D. J. (1991). 16S/23S rRNA sequencing. In Nucleic Acid Techniques in Bacterial Systematics, pp. 115-176. Edited by E. Stackebrandt \& M. Goodfellow. Chichester: Wiley.

Marmur, J. (1961). A procedure for the isolation of deoxyribonucleic acid from microorganisms. J Mol Biol 3, 208-218.

Nielsen, D. S., Teniola, O. D., Ban-Koffi, L., Owusu, M., Andersson, T. \& Holzapfel, W. H. (2007). The microbiology of Ghanaian cocoa fermentations analysed using culture-dependent and cultureindependent methods. Int J Food Microbiol 114, 168-186.

Rodas, A. M., Chenoll, E., Macian, M. C., Ferrer, S., Pardo, I. \& Aznar, R. (2006). Lactobacillus vini sp. nov., a wine lactic acid bacterium homofermentative for pentoses. Int J Syst Evol Microbiol 56, 513-517.
Schillinger, U. \& Lücke, F. K. (1987). Identification of lactobacilli from meat and meat products. Food Microbiol 4, 199-208.

Schwan, R. F. \& Wheals, A. E. (2004). The microbiology of cocoa fermentation and its role in chocolate quality. Crit Rev Food Sci Nutr 44, 205-222.

Stackebrandt, E. \& Kandler, O. (1978). Taxonomy of the genus Cellulomonas, based on phenotypic characters and deoxyribonucleic acid-deoxyribonucleic acid homology and proposal of seven neotype strains. Int J Syst Bacteriol 29, 273-282.

Torriani, S., Van Reenen, G. A., Klein, G., Reuter, G., Dellaglio, F. \& Dicks, L. M. T. (1996). Lactobacillus curvatus subsp. curvatus subsp. nov. and Lactobacillus curvatus subsp. melibiosus subsp. nov. and Lactobacillus sake subsp. sake subsp. nov. and Lactobacillus sake subsp. carnosus subsp. nov., new subspecies of Lactobacillus curvatus Abo-Elnaga and Kandler 1965 and Lactobacillus sake Katagiri, Kitahara, and Fukami 1934 (Klein et al. 1996, emended descriptions), respectively. Int J Syst Evol Microbiol 46, 1158-1163.

Wayne, L. G., Brenner, D. J., Colwell, R. R., Grimont, P. A. D., Kandler, O., Krichevsky, M. I., Moore, L. H., Moore, W. E. C., Murray, R. G. E. \& other authors (1987). International Committee on Systematic Bacteriology. Report of the ad hoc committee on reconciliation of approaches to bacterial systematics. Int J Syst Bacteriol 37, 463-464. 